and diphenhydramine ${ }^{2}$ have shown no advantage over placebo from the point of view of patient or doctor. In a brief experience so far our patients appear to have tolerated examinations satisfactorily without any pharyngeal anaesthesia. It may thus be unnecessary as well as potentially dangerous.I am, etc.,

St. Thomas's Hospital,

P. B. Cotton

London S.E.

1 Buchanan, D. P., American fournal of Digestive Diseases, 1960, 5, 121.

Spournal of Digestive Diseases, 1967, American

\section{Harry's Angels}

SIR,-How refreshing to read the story from South Africa under the title "Harry's Angels" (4 November, p. 288). It lifts one's spirit to hear of a team of highly-skilled specialists from Johannesburg who sacrifice their leisure weekends to travel by air to and from Swaziland (that small country with one doctor to 8,000 patients) in order to create, at their own expense, a first-class free medical and surgical service there, until such time as the country can supply its own needs. - I am, etc.,

Hove, Sussex

OLIVE K. BURNETT

\section{Foley-catheter Induction of Labour}

SIR,-The method described by Mr. J. R. Saunders (28 October, p. 237) deserves to be widely known. It has the great advantage of not compromising the patient's physical or mental condition. Further, when delivery is not urgent and there is time for its leisurely employment, it is, in cases when the cervix is unfavourable, a most effective insurance against failure of induction.

The patient is hardly aware of the catheter after its insertion. The membranes have not been ruptured; there is no risk of sepsis. There is no prolonged period of draining liquor and the patient is not attached to an oxytocin infusion or sucking Pitocin tablets by day and unable to take her normal meals. A course common with induction with the unripe cervix, which is encouraged by anxiety and starvation and which leads to acidosis and incoordinate labour, is never begun. The Foley catheter does not compromise the fetal condition. Oxytocin infusion, buccal Pitocin, and amniocentesis can all adversely affect it sooner or later.

The method has great value in cases where the patient has previously been subjected to caesarean section for inco-ordinated uterine action. I have concluded that there have been many cases when this method of induction might have avoided the original operation.-I am, etc.,

Shaw, Near Swindon

W. G. Dawson Wilts

\section{The "Dysarthria Address"}

SIR,-Throughout various medical centres in the world and particularly in hospitals in the United Kingdom the patient is asked to say "37 West Register Street, Edinburgh," one of the common phrases used in testing for dysarthria. During a recent visit to Edinburgh I decided to determine what is located at that famous address.
Following West Register Street from Saint Andrew's Square the numbers ceased in the 40s and continued from 19 somewhat further down the street. Occupying most of this numberless gap was an office building with a temporary sign pasted on its door. The inhabitants of the building did not know its street number, and therefore the query was referred to the supervisor. With puzzled look, he admitted that they only recently had transferred their office to the present location and ruefully noted that he did not know the number of the building. His curiousity aroused, we walked up and down West Register Street together trying to decide where " 37 " would be. We concluded that it was one of the many numbers encompassed by the building housing his office.

If so, 37 West Register Street is one of of the Royal Bank of Scotland.-I am, etc.,

George J. Dohrmann

The National Hospital, Queen Square,

London W.C. 1

\section{Association between Anaemia and Hypolipidaemia}

SIR,-The paper by Professors L. E. Böttiger and L. A. Carlson (23 September, p. 731) is of interest since it suggests a hypothesis known but hitherto unexplained association between anaemia and hypolipidaemia. The hypothesis assumes a constant total blood volume and a constant plasma cholesterol pool size, so that an increase in packed cell volume (P.C.V.) produces a rise in plasma cholesterol concentration secondary to the contraction in plasma volume.

Professors Böttiger and Carlson studied subjects with haemoglobin values in the normal range, and it is not known if their conclusions can be extrapolated to the anaemic situation. Data collected for a different purpose from five subjects with pernicious anaemia, at the time of diagnosis and during response to treatment, are given in the Table below together with the change in serum cholesterol which would have been predicted by the Böttiger-Carlson hypothesis.

In every case the observed increase in plasma cholesterol exceeds that predicted by the Böttiger-Carlson hypothesis, and overall the observed increase is of the order of twice the predicted increase. Professors Böttiger and Carlson were careful to state that their hypothesis "may in part account for the positive correlation between haemoglobin and plasma lipids" [my italics], and the data given here suggest that it may indeed be necessary to postulate an alteration in either or both of total blood volume and plasma cholesterol the addresses of the Public Relations Office which may explain, at least in part, the long-

pool size to explain the rise in plasma cholesterol concentration which occurs when anaemia is treated. Huber, Lewis, and Szur ${ }^{1}$ found little evidence of any change in total blood volume over the P.C.V. range $20-50 \%$, so it seems likely that there is an increase in plasma cholesterol pool size when anaemia is treated, but clearly more direct evidence is needed before this can be stated unequivocally.-I am, etc.,

Royal Posgtraduate Medical Schoo J. P. Miller London, W. 12

1 Huber, H., Lewis, S. M., and Szur, L., British fournal of Haematology, 1964, 10, 567.

\section{Infertility after the Pil}

SIR,-Your leading article on infertility after the pill (14 October, p. 59) reminds me that a few years ago you published a letter from me, ${ }^{1}$ the gist of which was to point out the possibility of this in certain cases.

My view ${ }^{2}$ has always been that there is an appreciable number, if a small percentage, of young and apparently normal women in whom some degree of hormonal dysfunction exists resulting in endometrial change and merstrual disturbance unrecognizable by the individual. This group is at risk in coping with the interference with the function of the hypothalamus consequent upon taking the pill over a lengthy period of time. In such cases the prolonged and somewhat unpredictable treatment by clomiphene and pituitary gonadotrophin cannot be altogether satisfactory.

In order to minimize the possibility of lifelong disappointment in these women $I$ suggest that a pelvic examination, and a diagnostic curettage if necessary, be carried out in all cases exhibiting the slightest menstrual irregularity before prescribing the pill. If such a procedure is impracticable I think these cases will increase in number in these days in which oral contraceptives are regarded as a universal panacea.-I am, etc.,

Altrincham, Cheshire

K. VERnon BAILEY

1 Bailey, K. V., British Medical fournal, 1969, 1, 2 Bailey, K. V., Fournal of Obstetrics and Gynaecology of the British Empire, 1959, 66, 556.

\section{Tumours of the Salivary Glands}

SIR,-Salivary tumours occur predominantly in the parotid gland, and the advances in parotid surgery in the past quarter-century have largely solved the problem of treatment of all except the uncommon highly malignant tumours of this organ. These advances have depended on the adoption of the

\begin{tabular}{|c|c|c|c|c|c|}
\hline Patient & P.C.V. & $\underset{\%}{(100-P . C . V .)}$ & $\begin{array}{c}\text { Plasma } \\
\text { Cholesterol } \\
\mathrm{mg} / 100 \mathrm{ml}\end{array}$ & $\begin{array}{l}\text { Change in } \\
\text { Plasma } \\
\text { Cholesterol } \\
\text { mg/100 ml }\end{array}$ & $\begin{array}{c}\text { Predicted Change } \\
\text { in Plasma } \\
\text { Cholesterol } \\
\text { mg/100 ml }\end{array}$ \\
\hline H.C. & $\begin{array}{l}15 \\
28 \\
41\end{array}$ & $\begin{array}{l}85 \\
72 \\
59\end{array}$ & $\begin{array}{l}115 \\
157 \\
205\end{array}$ & $\begin{array}{r}0 \\
+42 \\
+90\end{array}$ & $\begin{array}{r}0 \\
+21 \\
+51\end{array}$ \\
\hline J.D. & $\begin{array}{l}29 \\
46\end{array}$ & $\begin{array}{l}71 \\
54\end{array}$ & $\begin{array}{l}178 \\
264\end{array}$ & $\begin{array}{r}0 \\
+86\end{array}$ & $\begin{array}{r}0 \\
+56\end{array}$ \\
\hline G.R. & $\begin{array}{l}36 \\
47\end{array}$ & $\begin{array}{l}64 \\
53\end{array}$ & $\begin{array}{l}199 \\
281\end{array}$ & $\begin{array}{r}0 \\
+82\end{array}$ & $\begin{array}{r}0 \\
+41\end{array}$ \\
\hline J.B. & $\begin{array}{l}23 \\
40\end{array}$ & $\begin{array}{l}77 \\
60\end{array}$ & $\begin{array}{l}158 \\
293\end{array}$ & $\begin{array}{r}0 \\
+135\end{array}$ & $\begin{array}{r}0 \\
+45\end{array}$ \\
\hline I.Q. & $\begin{array}{l}28 \\
33 \\
37 \\
40\end{array}$ & $\begin{array}{l}72 \\
67 \\
63 \\
60\end{array}$ & $\begin{array}{l}120 \\
139 \\
157 \\
211\end{array}$ & $\begin{array}{r}0 \\
+19 \\
+37 \\
+91\end{array}$ & $\begin{array}{r}0 \\
+9 \\
+17 \\
+24\end{array}$ \\
\hline
\end{tabular}

